Марцин Т.О., к. т. н., дой. Київський національний торговельно-економічний університет, м. Київ, Україна Google Scholar https://scholar.google.com.ua/citations?user=U3T4k20AAAAJ\&hl=ru

\title{
ІННОВАЦІЙНІ ТЕХНОЛОГІЇ БЕЗДРІЖЖОВИХ БУЛОЧНИХ ВИРОБІВ
}

Сучасний стан харчування, зокрема в Україні, не можна назвати задовільним. Більша частина населення є носіями «хвороб цивілізації»: серцево-судинні захворювання, ожиріння, цукровий діабет. В Україні за даними 2017 року 50\% населення старше 35 років мають надлишкову вагу i ожиріння. Однією із причин цього є прийом у кількісному і якісному відношенні неповноцінної їжі, а відповідно і дефіцит поживних речовин. Як перший крок, в Україні запущено проект «Здорове харчування для дітей», за підтримки Асоціації дієтологів України та Центру громадського здоров'я Міністерства охорони здоров'я України. Це дозволить привернути увагу молоді до здорового способу життя [1].

Булочні вироби традиційно користуються великим попитом серед населення, а особливо у дітей. 3 метою створення булочних виробів збагачених білками, харчовими волокнами, макро- і мікроелементами розглянуто різні види сировини. Науковці досліджували питання щодо можливості та доцільності використання в технології булочних виробів хмельових заквасок, пророслого зерна пшениці, гарбузового пюре, шроту розторопші та концентрату квасного сусла, молочної сироватки, сухих фініків та інжиру [2], а також процес заміни борошна пшеничного I сорту на продукти переробки білого харчового люпину [3].

Огляд науково-технічної літератури i патентної інформації дозволив встановити, що використання суміші пшеничних та вівсяних висівок та кисломолочного сиру $є$ новітнім напрямком наукових досліджень в Україні і має шанси для подальшого його розвитку.

Вівсяні висівки містять у своєму складі близько 20 необхідних для людського організму кислот, а також багатий вітамінний ряд: A, E, C, вітаміни групи В, магній, натрій, кальцій, залізо, бром, йод, цинк. Пшеничні висівки містять достатню кількість клітковини, 
вітамінів групи В, які чинять позитивний вплив на серцево - судинну, нервову, м’язову систему, а також нормалізують гормональний баланс.

Досліджено вплив різних співвідношень суміші вівсяних та пшеничних висівок на технологічні показники і якість булочного виробу. Визначення оптимального кількісного співвідношення висівок не лише покращує хімічний склад булочки, а й забезпечує відповідну якість готової продукції. В ході роботи були створені модельні композиції, в яких було замінено пшеничне борошно на пшеничні та вівсяні висівки у різних співвідношеннях. Для однорідної структури та збагачення виробів кальцієм і тваринними білками було додано кисломолочний сир.

Для поліпшення смакових властивостей та підвищення харчової цінності булочки доцільно використовувати фісташки, горіхи кеш'ю, aрахіс, волоські горіхи, насіння гарбуза та соняшника. Всі вони володіють антиоксидантними та антибактеріальними властивостями, здатні регулювати рівень цукру в крові і легко засвоюватися.

При повній заміні пшеничного борошна на пшеничні та вівсяні висівки видно, що зовні відмінності є: виріб більш темного кольору, пористість виробу зменшується на 58\% в порівнянні 3 контролем, а висота підйому - на 72\%. Дослідження органолептичних показників показало, що дослідні зразки характеризувалися приємним ароматом, гарною консистенцією та хлібним присмаком.

При приготуванні бездріжджової булочки на основі вівсяних та пшеничних висівок додавали кисломолочний 9\% сир та яйця. Для збагачення вітамінного складу булочки додатково вводили гідратоване насіння льону. Сформовану булочку панірували у пшеничних висівках. Час випікання булочного виробу з висівками -40 хв. при $\mathrm{t}=180^{\circ}$.

Покращується поживна цінність бездріжджового булочного виробу. Вміст клітковини збільшується в 3 рази, а вітаміну Е на $31 \%$, знижується вміст вуглеводів на 50\% та жирів на $72 \%$.

У зв'язку зі стрімкою пропагандою ведення здорового способу життя, бездріжджова булочка здатна задовольнити потреби споживача, який піклується про своє здоров'я, а також рекомендується для споживання людям, які хворіють целіакією, цукровим діабетом та ожирінням. Булочка $є$ конкурентоспроможною по відношенню до численних булочних борошняних виробів на споживчому ринку і здатна розширити асортимент бездріжджових булочних виробів. 


\section{Список бібліографічних посилань}

1. МО3 України представило рекомендації зі здорового харчування. Режим доступу : http://moz.gov.ua/article/news/moz-ukrainipredstavilo-rekomendacii-zi-zdorovogo-harchuvannja

2. Бодак М. П. Використання нетрадиційної сировини для хлібобулочних виробів // Вісник Львівської комерційної академії. Збірник наукових праць. Серія товарознавча. Випуск 14, 2014. C.113-116

3. Ратошнюк В. I. Доцільність використання продуктів переробки безалкалоїдного люпину для підвищення харчової і біологічної цінності хлібобулочних виробів // Наукові доповіді НУБіП України № 4 (68), 2017. - С. 95-104 